TEME, г. XLIII, бр. 2, април - јун 2019, стр. 489-510

Прегледни рад

https://doi.org/10.22190/TEME180407030M

Примљено: 7. 4. 2018

UDK 338.2(497.11)

Одобрено за штампу: 13. 9. 2018.

\title{
USING COMPARATIVE ADVANTAGE OF THE REPUBLIC OF SERBIA IN THE FUNCTION OF INCREASING THE EXPORT EFFECTS
}

\author{
Vladislav Marjanović", Maja Marjanović \\ University of Niš, Faculty of Economy, Niš, Serbia \\ *marjanovic_vladislav@yahoo.com
}

\begin{abstract}
For many years, the Republic of Serbia has had a huge problem with balance of payment, which can be seen in chronic deficit in the current balance. Small and inadequate supply and large export demand caused by structural and economic system `s problems are the main reason for such a situation. Regardless the fact that the balance on services of the Republic of Serbia has recorded permanent surplus for years (with an exception of few years when it was in deficit due to errors of economic policy) it is not able to fill in the gaps between export and import of balance on goods, which has been chronically in deficit for decades. Because of that, the future economic policy of the Republic of Serbia should be directed to long-term solutions of problems of the balance of payment, in the sense of its sustainable deficit. This means that the increase in export should be an imperative in the long run, and restructuring of the economy in the sense of increasing the share of export-propulsive sectors is a condition sine qua non.

In order for effects of export to be higher and to have positive effects on the balance of payment and the competitiveness of the Republic of Serbia, all comparative advantages of the economy should be used and their shift to competitive advantages should be speeded up. In this regard, this paper will particularly analyze the "revealed comparative advantages". We will make an attempt to identify crucial sectors and groups, which show revealed comparative advantages, with a special focus on identifying service sectors, which traditionally record surplus in the foreign trade.
\end{abstract}

Key words: comparative advantages, foreign trade, export, balance of payment, economic structure. 


\title{
ИСКОРИШЋЕЊЕ КОМПАРАТИВНИХ ПРЕДНОСТИ РЕПУБЛИКЕ СРБИЈЕ У ФУНКЦИЈИ ПОВЕһАЊА ЕФЕКАТА ИЗВОЗА
}

\begin{abstract}
Апстракт
Република Србија већ дуги низ година има велики платнобилансни проблем, који се огледа у хроничном дефициту текућег биланса. Мала и неадекватна извозна понуда и велика увозна тражња узроковане структурним и привредно-системским проблемима главни су узрочници овакве ситуације. Без обзира на то што биланс услуга Републике Србије бележи стални суфицит годинама уназад (изузев неколико година када је углавном због грешака економске политике био у дефициту), он није у стању да попуни велики јаз између увоза и извоза робног биланса, који је у хроничном дефициту деценијама уназад. Због тога би будућа економска политика Републике Србије требало да буде усмерена ка дугорочном решавању проблема платног биланса, у смислу његовог одрживог дефицита. То значи да ће повећање извоза бити императив на дуги рок, а реструктурирање привреде, у смислу повећања удела извозно-пропулзивних сектора, услов без кога се не може.

Да би ефекти извоза били већи и позитивно утицали на платни биланс и конкурентност привреде Републике Србије, морају се искористити све компаративне предности привреде и обезбедити њихов бржи прелаз у конкурентске предности. С тим у вези, у раду се посебно бавимо анализом „откривених компаративних предности". У раду ће бити учињен покушај идентификовања кључних сектора и робних група који показују откривене компаративне предности, са посебним акцентом на идентификовање услужних сектора, који у спољној трговини традиционално бележе суфицит.
\end{abstract}

Кључне речи: компаративне предности, спољна трговина, извоз, платни биланс, привредна структура.

\section{INTRODUCTION}

The division of trade into domestic and foreign is more a convention than the reality, because, seen from the economic perspective, both domestic and foreign trade comprise a unique trade activity, which performs the turnover function in the cycle of reproduction. The differences between domestic and foreign trade emphasized by economic theory are mainly related to: the area of activity, climate differences, demographic differences, differences in legislation, distance between partners, and the intensity of interventionism of particular countries. In the broadest sense, under the term foreign trade one understands all forms of economic cooperation of a country with abroad. In the narrow sense, foreign trade encompasses trade of goods and services by one country with abroad.

What the contemporary economic analysis gives special attention to is the connection between foreign trade and economic development. Understood in its narrowest sense, foreign trade appears to be an inevitable component of every national economy regardless of the level of development or the size of a country, because no economy can be self- 
sufficient, especially not the economy of small or medium counties (Krugman, Obstfeld, 2000).

In broader perspective, foreign trade has the following important functions: it is an important mediator in expanding new technology, new ideas, production experiences, new methods of organization and management; it is a basic mechanism of international flow of capital; it is a necessary mechanism of international labor division and specialization among countries.

The Republic of Serbia has for many years had a large problem of balance of payment, which is seen in chronic deficit of current balance, caused by structural and economic system`s problems. Regardless the fact that the balance on services of the Republic of Serbia has recorded permanent surplus for years, it is not possible for it to fill in a great gap between export and import of balance on goods, which has been chronically in deficit. The future economic policy of the Republic of Serbia should be directed at longterm solution for the problem of balance of payment, in the sense of its sustainable deficit. This means that an increase in export will be an imperative for a long period of time, and the restructuring of the economy in the sense of increasing the share of export-propulsive sectors is a condition sine qua non.

What can be pointed to as the basic comparative advantage of the Republic of Serbia, from the perspective of development strategy, and what should be used in order to increase investments and future export is: optimal geographic location, availability of high-qualified workers, competitive operative expenses, duty-free access to 1.1 billion consumers, and financial incentives (Serbian Development Agency, 2016).

In order to increase the effects of export and to make them beneficial to balance of payment and competiveness of the economy of the Republic of Serbia, one has to use all comparative advantages and to secure their faster shift to competitive advantages. The paper deals especially with the analysis of the revealed comparative advantages, and we will make an effort to identify crucial sectors and commodity groups, which exhibit the revealed comparative advantages. Special attention will be given to identifying services sectors, which traditionally record surplus in international trade.

In the first part of the paper, titled "Foreign trade and balance of payment of the Republic of Serbia in the new external environment", we will present the dynamics and the structure of the foreign trade of the Republic of Serbia, and thereafter we will present the revealed comparative advantages of the sectors of the standard international trade classification of the Republic of Serbia. This part pays special attention to measuring the revealed comparative advantages of the branches of the manufacturing industry of the Republic of Serbia, as the dominant sector in creating gross national product.

The second part of the paper is titled "The strategy of stimulating export of the Republic of Serbia" is an attempt to identify potential export propulsive sectors in the Republic of Serbia. This part especially 
emphasizes possibilities and prospects of increasing export in the EU countries, which are the largest and traditional export market of Republic of Serbia. This part especially deals with the possibilities for export of the real sector, i.e. export of goods and particularly with the prospect of export of certain services of the Republic of Serbia, which are to be more carefully considered in the future strategy of foreign trade of the Republic of Serbia

\section{METHODOLOGY AND HYPOTHESES}

In this paper, beside classical methods of scientific analysis, we will especially use the comparative method, which will indicate trends of the structure of foreign trade of the Republic of Serbia and the EU, as well as the balance of payment of the Republic of Serbia (and the subbalance) over the years and will draw certain conclusions regarding the trends. Furthermore, the comparative method will also show the trend of the balance of payment of the EU, which is very indicative for offering certain recommendations for economic policy in the sense of increasing export of certain sectors. The paper will also use the method of quantitative analysis, with which we will measure the index of the revealed comparative advantages (RCA) of a sector according to an international trade classification, which is the simplest way to discover which sectors could be the backbone of the future export run of the Republic of Serbia.

Since the paper deals specifically with the so called revealed comparative advantages of the Republic of Serbia, we use the RCA index for that purpose, which measures comparative advantages of a national economy. There are several mathematical variations of this index in the literature, and we will use the simplified version that has the following formula:

$$
R C A=\frac{X j-M j}{X j+M j},
$$

where $X_{j}$ is the value of export of a product $j$ (or a sector $j$ ), and $M_{j}$ is the value of import of a product $j$ (or sector $j$ ) (Jefferson Institute, 2003).

In this case, the index takes values from 0 to 1 . This means that the closer the index is to 1, comparative advantages are higher, the closer it is to 0 , comparative advantages are lower. If this index is negative, then it is said that there are no comparative advantages in export of this product.

The paper should confirm the following starting hypotheses:

1. the main cause of payment balance problems of the Republic of Serbia is chronic deficit of balance on goods,

2. deficit of the balance on goods causes structural and economic system's problems,

3. the Republic of Serbia does not have an adequate export supply,

4. the only long term solution for the problem of deficit is restructuring of the economy and the increase of export. 


\section{FOREIGN TRADE AND THE BALANCE OF PAYMENT OF THE REPUBLIC OF SERBIA IN NEW EXTERNAL ENVIRONMENT}

\subsection{The Dynamics of Foreign Trade and the Balance of Payment of the Republic of Serbia}

It is a fact that the foreign trade activity of the Republic of Serbia has been intensified in the past few years in a positive way, which is shown by the balance of payment of the Republic of Serbia, as seen in the data that follows. After the period of crisis in 2007 and 2008, when the greatest difference between export and import of Serbia had been recorded, a period of stabilization of foreign trade followed, and one can notice that the negative foreign trade account decreased year after year.

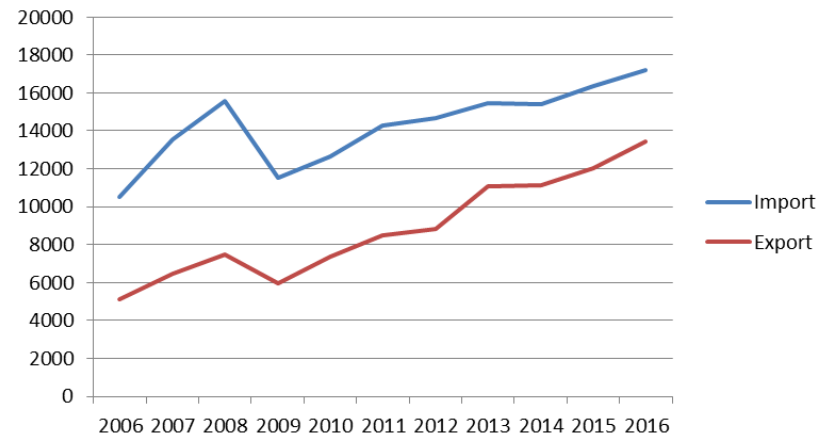

Graph 1. Foreign trade balance of the Republic of Serbia

Source: Directorate General for Trade. (2017). European Union, Trade with Serbia. Brussels: European Commission, pg. 8.

First, we will observe the structure of the foreign trade of the Republic of Serbia according to different criteria, starting from geographic to commodity structure.

Table 1. The most important foreign trade partners of Serbia, 2016

\begin{tabular}{lrlr}
\hline Export & & Import & \\
\hline World & 13423 & World & 17177 \\
EU 28 & 8921 & EU 28 & 10944 \\
Bosnia and Herzegovina & 1123 & China & 1447 \\
Russia & 693 & Russia & 1277 \\
Montenegro & 666 & Turkey & 581 \\
FJR Macedonia & 519 & Bosnia and Herzegovina & 409 \\
Turkey & 230 & USA & 297 \\
USA & 208 & Ukraine & 200 \\
Switzerland & 96 & Switzerland & 194 \\
Albania & 91 & FJR Macedonia & 191 \\
UAE & 77 & Iraq & 128 \\
\hline
\end{tabular}

Source: Directorate General for Trade. (2017). European Union, Trade with Serbia.

Brussels: European Commission, pg. 8. 
It can be noticed that the EU has been our biggest foreign trade partner for many years (when it comes both to export and to import). The table shows that more than $60 \%$ of the foreign trade of the Republic of Serbia is with the EU countries, that are followed by the former Yugoslav republics Bosnia and Herzegovina and Macedonia. These are followed by Russia, Turkey, USA and Switzerland. Among other significant export markets of Republic of Serbia there are also Montenegro, Albania and UAE.

Regarding the main import destinations of the Republic of Serbia, beside those already mentioned countries, there are also China, Ukraine and Iraq.

If we take a look at the structure of the foreign trade of the Republic of Serbia according to classification of activities, we can see that manufacturing industry is a dominant activity in the foreign trade, and then agriculture, forestry and fishing.

Table 2. Foreign trade structure of Republic of Serbia by classification of activities (mil. \$)

\begin{tabular}{|c|c|c|c|c|c|c|}
\hline & \multicolumn{2}{|c|}{2013} & \multicolumn{2}{|c|}{2014} & \multicolumn{2}{|c|}{2015} \\
\hline & Export & Import 1 & Export & Import & Export & Import \\
\hline Agriculture, forestry and fishing & 865 & 595 & 979 & 630 & 946 & 605 \\
\hline Mining and quarrying & 87 & 2231 & 80 & 1972 & 52 & 1649 \\
\hline Manufacturing & 13073 & 15992 & 13385 & 16210 & 12076 & 14203 \\
\hline $\begin{array}{l}\text { Electricity, gas, steam and air } \\
\text { conditioning supply }\end{array}$ & 272 & 160 & 84 & 150 & 96 & 95 \\
\hline $\begin{array}{l}\text { Water supply; sewerage, waste } \\
\text { management and remediation } \\
\text { activities }\end{array}$ & 242 & 114 & 227 & 113 & 133 & 96 \\
\hline Information and communication & 67 & 80 & 86 & 72 & 72 & 57 \\
\hline $\begin{array}{l}\text { Professional, scientific and } \\
\text { technical activities }\end{array}$ & 0 & 1 & 3 & 0 & 2 & 0 \\
\hline Arts, entertainment and recreation & 3 & 0 & 0 & 1 & 1 & 0 \\
\hline Other service activities & - & 0 & 0 & 0 & 0 & 0 \\
\hline Unclassified & 1 & 1377 & 2 & 1452 & 1 & 1504 \\
\hline
\end{tabular}

For this occasion we will analyze also the structure of foreign trade according to the Standard International Trade Classification (SITC) (Table 3). It can be seen in the table that Serbia has a positive account in the following groups: food and live animals, beverage and tobacco, animal and vegetable fats. This is not very flattering, since these are all products of low technological level, which cannot be used to increase competitiveness in the long run.

If we take a look at the structure of foreign trade of Serbia by destination, we can see that intermediate goods participate with the greatest percentage, and then consumer goods and capital goods. 
Table 3. Foreign trade structure of Republic of Serbia by SITC (mil. \$)

\begin{tabular}{|c|c|c|c|c|c|c|c|c|c|c|}
\hline \multirow[b]{2}{*}{ Year } & \multicolumn{2}{|c|}{$\begin{array}{l}\text { Food and live } \\
\text { animals }\end{array}$} & \multicolumn{2}{|c|}{$\begin{array}{l}\text { Beverages and } \\
\text { tobacco }\end{array}$} & \multicolumn{2}{|c|}{$\begin{array}{c}\text { Crude } \\
\text { materials, } \\
\text { except fuels }\end{array}$} & \multicolumn{2}{|c|}{$\begin{array}{l}\text { Mineral fuels } \\
\text { and lubricants }\end{array}$} & \multicolumn{2}{|c|}{$\begin{array}{c}\text { Animal and } \\
\text { vegetable fats }\end{array}$} \\
\hline & Export & Import & Export & Import & Export & Import & Export & Import & Export & Import \\
\hline 2011 & 2092 & 1055 & 274 & 198 & 656 & 792 & 496 & 3963 & 201 & 45 \\
\hline 2012 & 2095 & 1104 & 286 & 185 & 560 & 615 & 401 & 3320 & 196 & 51 \\
\hline 2013 & 2097 & 1207 & 320 & 209 & 652 & 641 & 705 & 3112 & 189 & 69 \\
\hline 2014 & 2367 & 1330 & 398 & 210 & 544 & 660 & 554 & 2908 & 151 & 60 \\
\hline \multirow[t]{2}{*}{2015} & 2088 & 1143 & 441 & 225 & 449 & 747 & 381 & 2097 & 157 & 52 \\
\hline & \multicolumn{2}{|c|}{$\begin{array}{l}\text { Chemical } \\
\text { products }\end{array}$} & \multicolumn{2}{|c|}{$\begin{array}{l}\text { Manufactured } \\
\text { goods }\end{array}$} & \multicolumn{2}{|c|}{$\begin{array}{l}\text { Machinery and } \\
\text { transport } \\
\text { equipment }\end{array}$} & \multicolumn{2}{|c|}{$\begin{array}{l}\text { Miscellaneous } \\
\text { manufactured } \\
\text { goods }\end{array}$} & \multicolumn{2}{|c|}{$\begin{array}{c}\text { Products not } \\
\text { elsewhere } \\
\text { specified }\end{array}$} \\
\hline Year & Export & Import & Export & Import & Export & Import & Export & Import & Export & Import \\
\hline 2011 & 1002 & 2975 & 3481 & 3843 & 1961 & 4526 & 1510 & 1510 & 106 & 954 \\
\hline 2012 & 909 & 3135 & 2573 & 3478 & 2545 & 4533 & 1552 & 1356 & 108 & 1146 \\
\hline 2013 & 1249 & 3168 & 2913 & 3560 & 4535 & 5628 & 1831 & 1565 & 120 & 1393 \\
\hline 2014 & 1195 & 3084 & 3108 & 3712 & 4465 & 5572 & 1942 & 1606 & 121 & 1457 \\
\hline 2015 & 1131 & 2732 & 2871 & 3293 & 3896 & 5075 & 1762 & 1336 & 204 & 1511 \\
\hline
\end{tabular}

Source: Statistical office of the Republic of Serbia. (2016). Statistical Yearbook 2016.

Belgrad: Statistical office of the Republic of Serbia, pg. 319 - 320.

Table 4. Foreign trade structure of Republic of Serbia by destination (mil. \$)

\begin{tabular}{lrrrrrr}
\hline & \multicolumn{2}{c}{2013} & \multicolumn{2}{c}{2014} & \multicolumn{2}{c}{2015} \\
\cline { 2 - 7 } & Export & Import & Export & Import & Export & Import \\
\hline Capital goods & 1145 & 2327 & 1145 & 2415 & 1222 & 2328 \\
Intermediate goods & 7697 & 12902 & 7774 & 12695 & 7058 & 10699 \\
Consumer goods & 5767 & 3945 & 5924 & 4039 & 5098 & 3679 \\
Unclassified & 1 & 1377 & 2 & 1452 & 1 & 1504 \\
\hline
\end{tabular}

Source: Statistical office of the Republic of Serbia. (2016). Statistical Yearbook 2016. Belgrad: Statistical office of the Republic of Serbia, pg. 315.

This additionally confirms the fact that the Republic of Serbia has a poor structure of the foreign trade, which also somewhat means a poor economic structure and also the economy itself (in the most developed economies, the position "capital goods" is dominant). Regardless the fact that Serbia entered the second phase of competitiveness according to all parameters of the World Economic Forum (efficiency driven economies), this structure of the foreign trade by destination will certainly not speed up the third and the final phase of competitiveness (innovative).

Since the EU is by far the biggest foreign trade partner of the Republic of Serbia, we will pay special attention to the structure of the foreign trade between the Republic of Serbia and the EU. 


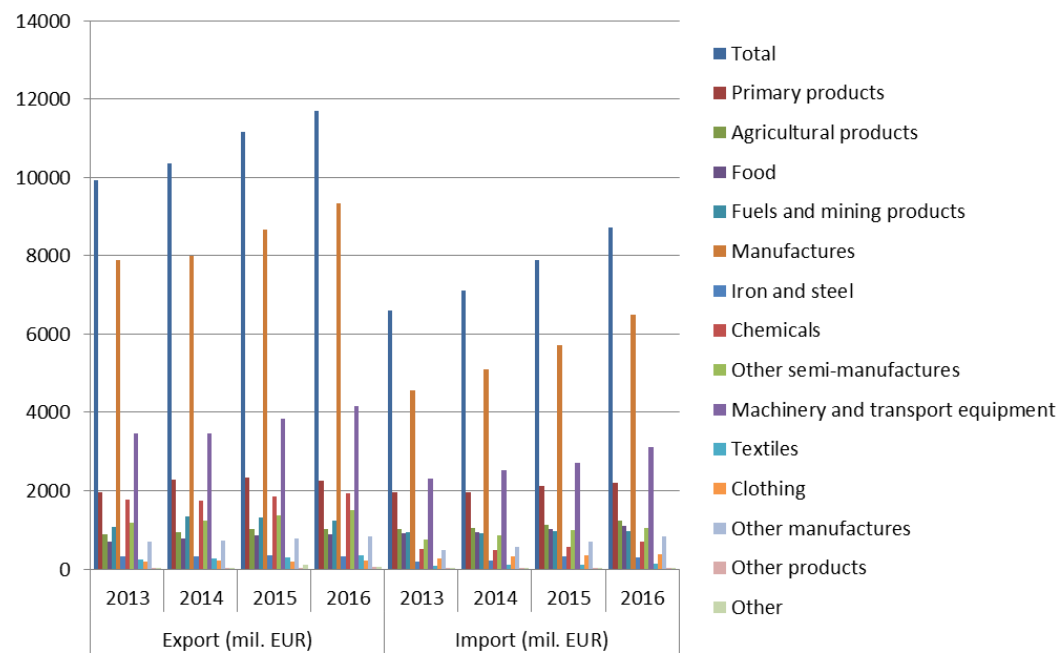

Graph 2. The dynamics of foreign trade of Serbia with the EU

Source: Directorate General for Trade. (2017). European Union, Trade with Serbia. Brussels: European Commission, pg 7.

It can be seen that what dominates in the foreign trade with the EU are: manufactures, machinery and transport equipment, primary products, agricultural products, food and other manufactures (respectively). Since 2013, an intensive growth in export of the Republic of Serbia into the EU countries has been recorded, but also an increase in import from the European countries, which is still by far greater than the Serbian export. Furthermore, increased dynamics of foreign trade (both export and import) is recorded in almost all SITC sectors.

What is necessary to emphasize as a positive trend in the last few years is a decrease in deficit of the current balance.

This is contributed both by the decrease of deficit of balance on goods of the Republic of Serbia, and by the increase in sufficit of the balance on services.

Regarding the capital account, we can record another positive trend of a small increase in foreign direct investments and reduction of longterm loans. Policymakers, however, must not let be deceived by such a trend, because these long-term credits from the previous period have been piled up, and, beside the problem with the balance of payment, the debt problem is one of the most prominent problems that we have with the external environment. 
Table 5. Balance of payment of Republic of Serbia (mil. EUR)

\begin{tabular}{|c|c|c|c|c|}
\hline & 2012 & 2013 & 2014 & 2015 \\
\hline 1. Current account & $-3,671$ & $-2,098$ & $-1,985$ & $-1,577$ \\
\hline 1.A. Goods and services & $-5,523$ & $-3,845$ & $-3,645$ & $-3,268$ \\
\hline 1.A.a. Goods & $-5,634$ & $-4,159$ & $-4,111$ & $-3,993$ \\
\hline Export & 8,376 & 10,515 & 10,641 & 11,357 \\
\hline Import & 14,011 & 14,674 & 14,752 & 15,350 \\
\hline 1.A.b. Services & 111 & 313 & 465 & 725 \\
\hline Export & 3,093 & 3,422 & 3,810 & 4,273 \\
\hline Import & 2,981 & 3,109 & 3,344 & 3,548 \\
\hline 1.B. Primary income & $-1,097$ & $-1,419$ & $-1,343$ & $-1,658$ \\
\hline 1.C. Secondary income & 2,949 & 3,166 & 3,003 & 3,349 \\
\hline 2. Capital account & -8 & 15 & 7 & -18 \\
\hline 3. Financial account & $-3,351$ & $-1,630$ & $-1,705$ & $-1,205$ \\
\hline 3.1. Direct investment & -753 & $-1,298$ & $-1,236$ & $-1,804$ \\
\hline 3.2. Portfolio investment & $-1,676$ & $-1,883$ & -369 & 289 \\
\hline 3.3. Financial derivatives & 2 & -1 & -6 & 2 \\
\hline 3.4. Other investment & 214 & 855 & 1,703 & 141 \\
\hline 3.4.1. Other equity & 0 & 0 & 0 & 0 \\
\hline 3.4.2. Currency and deposits & 156 & -228 & 830 & -218 \\
\hline 3.4.3. Loans & 316 & 1,286 & 757 & 230 \\
\hline $\begin{array}{l}\text { 3.4.4. Insurance, pension, and } \\
\text { standardized guarantee schemes }\end{array}$ & 3 & 0 & 0 & 0 \\
\hline 3.4.5. Trade credit and advances & -261 & -204 & 116 & 129 \\
\hline $\begin{array}{l}\text { 3.4.6. Other accounts } \\
\text { receivable/payable }\end{array}$ & 0 & 0 & 0 & 0 \\
\hline 3.5. Reserve assets & $-1,137$ & 697 & $-1,797$ & -166 \\
\hline 4. Net errors and omissions & 329 & 453 & 273 & 390 \\
\hline
\end{tabular}

\subsection{Revealed Comparative Advantages of the Republic of Serbia}

It has been clear for a long time, and besides it was proven by eminent scientists, that using comparative advantages can strongly increase the effects of export and improve the structure of the balance of payment of a national economy. In the following passages we will deal more concretely with the so called revealed comparative advantages of the Republic of Serbia, and for that purpose we will use the RCA index that measures comparative advantages of a national economy.

Just for a moment we will return to SITC sectors of the Republic of Serbia, and in the following table we can see the RCA indices for each of them. 
Table 6. RCA indices of SITC sectors of the Republic of Serbia

\begin{tabular}{lrrrrr}
\hline SITC sectors & 2011 & 2012 & 2013 & 2014 & 2015 \\
\hline Food and live animals & 0,31 & 0,31 & 0,27 & 0,28 & 0,29 \\
Beverages and tobacco & 0,16 & 0,21 & 0,21 & 0,31 & 0,32 \\
Crude materials, except fuels & $-0,09$ & $-0,05$ & 0,01 & $-0,1$ & $-0,25$ \\
Mineral fuels and lubricants & $-0,78$ & $-0,78$ & $-0,63$ & $-0,68$ & $-0,69$ \\
Animal and vegetable fats & 0,63 & 0,59 & 0,47 & 0,43 & 0,50 \\
Chemical products & $-0,50$ & $-0,55$ & $-0,43$ & $-0,44$ & $-0,41$ \\
Manufactured goods & $-0,05$ & $-0,15$ & $-0,10$ & $-0,09$ & $-0,07$ \\
Machinery and transport equipment & $-0,39$ & $-0,28$ & $-0,11$ & $-0,11$ & $-0,13$ \\
Miscellaneous manufactured goods & 0 & 0,07 & 0,08 & 0,09 & 0,14 \\
Products not elsewhere specified & $-0,79$ & $-0,83$ & $-0,85$ & $-0,85$ & $-0,76$ \\
\hline Source: own calculations based on: Statistical office of the Republic of Serbia. (2016). \\
\multicolumn{2}{c}{ Statistical Yearbook 2016. Belgrade: Statistical office of the Republic of Serbia. }
\end{tabular}

We can notice that the index is positive for four sectors: food and live animals, beverages and tobacco, animal and vegetable fats and miscellaneous manufactured goods. In other commodity groups the index is negative, which means that there are no revealed comparative advantages. The greatest RCA index is in the groups of animal and vegetable fats and beverages and tobacco. The RCA index in the sectors of food and live animals and animal and vegetable fats has had a cyclic tend over the past five years, while the sectors of beverages and tobacco and miscellaneous manufactured goods record a constant growth during this period. In all other SITC sectors the Republic of Serbia records a negative RCA index, and it is the greatest in mineral fuels and lubricants and products not elsewhere specified.

By looking at the vertical economic structure of the Republic of Serbia, it can be easily seen that the manufacturing industry participates in the greatest percentage in making the gross national product of the Republic of Serbia. This sector also employs the greatest number of workers, so it can be justly considered the most important (driving) sector in the economy and therefore we pay special attention to revealed comparative advantages to manufacturing activities (within the sector of manufacturing industry).

It can be clearly seen in the table that tobacco production had the greatest comparative advantages in 2015 , and it was followed by furniture production, beverages and food products. Noticeable growth of the RCA index was recorded in the production of tobacco products and furniture production during the observed period. Attention should also be drawn to the manufacture of wearing apparel, food, manufacture of fabricated metal products except machinery and equipment, manufacture of rubber and plastic. 
Table 7. RCA indices of manufacturing activities

\begin{tabular}{lrrr}
\hline & 2013 & 2014 & 2015 \\
\hline Manufacturing & $-0,10$ & $-0,09$ & $-0,08$ \\
Manufacture of food products & 0,28 & 0,27 & 0,24 \\
Manufacture of beverages & 0,45 & 0,41 & 0,34 \\
Manufacture of tobacco products & 0,02 & 0,31 & 0,57 \\
Manufacture of textiles & $-0,49$ & $-0,46$ & $-0,45$ \\
Manufacture of wearing apparel & 0,30 & 0,27 & 0,29 \\
Manufacture of leather and related products & 0,06 & 0,07 & 0,07 \\
Manufacture of wood and products of wood & 0,07 & 0,09 & 0,09 \\
Manufacture of paper and paper products & $-0,34$ & $-0,31$ & $-0,27$ \\
Printing and reproduction of recorded media & - & - & - \\
Manufacture of coke and refined petroleum products & $-0,35$ & $-0,34$ & $-0,38$ \\
Manufacture of chemicals and chemical products & $-0,45$ & $-0,49$ & $-0,48$ \\
Manufacture of basic pharmaceutical products & $-0,52$ & $-0,48$ & $-0,49$ \\
Manufacture of rubber and plastic products & 0,11 & 0,11 & 0,17 \\
Manufacture of basic metals & $-0,07$ & $-0,07$ & $-0,08$ \\
Manufacture of fabricated metal products except & 0,16 & 0,12 & 0,20 \\
machinery and equipment & & & \\
Manufacture of computer, electronic and optical products & $-0,57$ & $-0,55$ & $-0,61$ \\
Manufacture of electrical equipment & 0,09 & 0,12 & 0,09 \\
Manufacture of machinery and equipment n.e.c. & $-0,32$ & $-0,40$ & $-0,36$ \\
Manufacture of motor vehicles and trailers & $-0,05$ & 0,02 & $-0,001$ \\
Manufacture of other transport equipment & $-0,04$ & $-0,12$ & $-0,08$ \\
Manufacture of furniture & 0,26 & 0,36 & 0,42 \\
Other manufacturing & $-0,37$ & $-0,36$ & $-0,27$ \\
\hline Source: own calculations based on: Statistical office of the Republic of Serbia. & $(2016)$. \\
Statistical Yearbook 2016. Belgrade: Statistical office of the Republic of Serbia. & & &
\end{tabular}

\section{THE STRATEGY OF STIMULATION OF EXPORT OF THE REPUBLIC OF SERBIA}

\subsection{Identifying export-propulsive sectors of the Republic of Serbia based on comparative advantages}

The structural transformation of the economy of Serbia has entered the phase of unacceptable slowdown. This reflects the structure of foreign trade with negative effects on the current balance. If this trend would continue, it would bring the economy into the phase of regression and cause even deeper structural disproportions. Therefore, the process of restructuring has to start with an active role of the state.

How should the economy of Serbia be restructured? This complex and in this moment probably the most difficult macroeconomic question cannot be given a simple answer. In the order of activities, leading sectors of Serbian economy should be identified as an axis point of its development. Also, potential "driving" sectors should also be identified, which could give a direction to future structural changes and the future economic structure of Serbia. The structure of Serbia should be "set" in 
the way that would provide continuous economic growth in a long run, to reduce disproportion of the balance of payment, to increase competitiveness of the economy, to reduce unemployment and finally to increase standard of living.

Having in mid that Serbia has had a serious payment balance crisis for many years, because of relatively large deficit of the current balance, which has a structural background, it is of a crucial importance for the future strategy of restructuring Serbian economy, and thus for increasing the export effects, to observe sectors in international trade.

The EU is the largest foreign trade partner of Serbia. This fact is important not only because of the volume of foreign trade business, but also because of Serbian joining the EU. It is, however, alarming that Serbia records the largest foreign trade deficit with the EU, even though there are practically no customs duties for Serbian import into the EU, with an exception of four types of products (wine, sugar, beef and some sorts of fish) (Николић, 2008). Serbian export to the EU is "inhibited" by some non-tariff barriers, especially in exporting services to the market of the EU, where some standards are practically unreachable.

Serbia has also a possibility allowed by the EU to protect certain sectors with tariffs for some years, but gradually to liberalize that regime. Beside this, the structure of the foreign trade with the EU is quite unfavorable.

Having in mind that manufacturing industry is the most important sector of the Republic of Serbia, it is logically to start from a possibility that this sector makes products for international market. Table 8 shows countries that dominate in the world trade in manufacturing products. From the geographic perspective, the Republic of Serbia should emphasize not only the increase in export into the EU countries, but also to other world markets, such as USA, China, India and Japan.

The Republic of Serbia has the largest comparative advantage in the production of agricultural products and agroindustry, and we should take a look at Table 9, which shows the most important countries in the international trade in agricultural products. It is interesting to mention that in this group of the most important countries in the international trade in agricultural products, there are mostly countries that also dominate in trade in manufacturing products, which makes the already given conclusion on the future orientation of Serbian export to different markets more important. 
Table 8. The world's most important exporters and importers of manufacture (mil. \$ and \%)

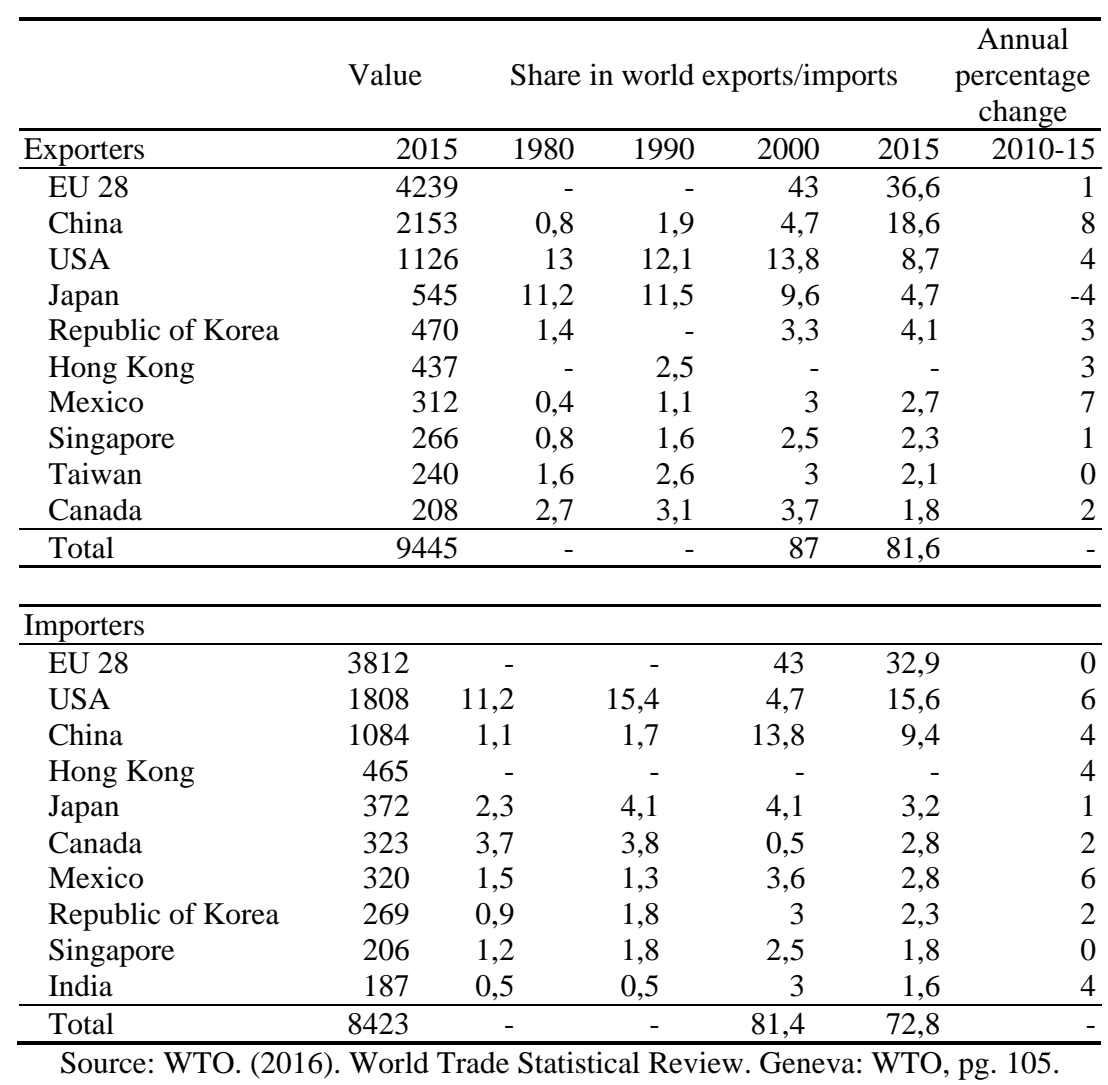


Table 9. The most important world exporters and importers of agricultural products (mil. \$ and \%)

\begin{tabular}{|c|c|c|c|c|c|c|}
\hline \multirow[b]{2}{*}{ Exporters } & \multirow{2}{*}{$\begin{array}{l}\text { Value } \\
2015\end{array}$} & \multicolumn{4}{|c|}{ Share in world exports/imports } & \multirow{2}{*}{$\begin{array}{c}\begin{array}{c}\text { Annual } \\
\text { percentage } \\
\text { change }\end{array} \\
2010-15 \\
\end{array}$} \\
\hline & & 1980 & 1990 & 2000 & 2015 & \\
\hline EU 28 & 585 & - & - & 41,9 & 37,1 & 2 \\
\hline USA & 163 & 17 & 14,3 & 13 & 10,4 & 3 \\
\hline Brazil & 80 & 3,4 & 2,4 & 2,8 & 5,1 & 3 \\
\hline China & 73 & 1,5 & 2,4 & 3 & 4,6 & 7 \\
\hline Canada & 63 & 5 & 5,4 & 6,3 & 4 & 4 \\
\hline Indonesia & 39 & 1,6 & 1 & 1,4 & 2,5 & 2 \\
\hline Thailand & 36 & 1,2 & 1,9 & 2,2 & 2,3 & 1 \\
\hline Australia & 36 & 3,3 & 2,9 & 3 & 2,3 & 6 \\
\hline India & 35 & 1 & 0,8 & 1,1 & 2,2 & 9 \\
\hline Argentina & 35 & 1,9 & 1,8 & 2,2 & 2,2 & 0 \\
\hline Total & 1146 & - & - & 76,9 & 72,7 & - \\
\hline Importers & 590 & - & - & 42,7 & 35 & 1 \\
\hline EU 28 & 160 & 2,1 & 1,8 & 3,3 & 9,5 & 8 \\
\hline China & 149 & 8,7 & 9 & 11,6 & 8,8 & 5 \\
\hline USA & 74 & 9,6 & 11,5 & 10,4 & 4,4 & -1 \\
\hline Japan & 38 & 1,8 & 2 & 2,6 & 2,3 & 4 \\
\hline Canada & 33 & 1,5 & 2,2 & 2,2 & 2 & 4 \\
\hline Republic of Korea & 28 & 0,5 & 0,4 & 0,7 & 1,6 & 9 \\
\hline India & 28 & 1,2 & 1,2 & 1,8 & 1,6 & 3 \\
\hline Mexico & 28 & - & - & 1,3 & 1,6 & -5 \\
\hline Russian Federation & 27 & - & - & - & - & 6 \\
\hline Hong Kong & 18 & 1 & 1 & 1,1 & 1,1 & 6 \\
\hline Total & 1154 & - & - & 77,6 & 67,9 & - \\
\hline
\end{tabular}

Source: WTO. (2016). World Trade Statistical Review. Geneva: WTO, pg. 104.

\subsection{Possibilities for increasing the export of goods to the $E U$}

It should be emphasized that the EU-28 has made significant improvement in its foreign trade in goods in the past ten years. Namely, in the pre-crisis period (2007), the deficit on goods of EU-27 was over 200 billion EUR, but more recently this integration has become net exporter with the positive score of balance on goods of 37 million EUR in 2016. 
Table 10. Balance of trade EU-28 (mil. EUR)

\begin{tabular}{clrrrrr}
\hline & & 2012 & 2013 & 2014 & 2015 & 2016 \\
\hline $0-9$ & Total & $-113,9$ & 79 & 10,7 & 60 & 36,9 \\
\hline 0 & Food and live animals & $-15,4$ & $-10,6$ & $-11,9$ & $-18,2$ & $-16,9$ \\
1 & Beverages and tobacco & 21,4 & 21,4 & 21,1 & 22,8 & 23,8 \\
2 & Crude materials, except fuels & $-28,6$ & $-26,8$ & $-25,4$ & $-24,3$ & $-21,7$ \\
3 & Mineral fuels and lubricants & $-421,5$ & $-377,9$ & $-335,2$ & $-242,9$ & $-190,2$ \\
4 & Animal and vegetable fats & $-4,6$ & $-3,9$ & $-4,1$ & $-4,3$ & $-3,8$ \\
5 & Chemical products & 112,1 & 115,4 & 113,4 & 129,7 & 129,1 \\
6 & Manufactured goods & 35,2 & 36,3 & 26,1 & 15,1 & 8,5 \\
7 & Machinery and transport equipment & 255,1 & 271,4 & 250 & 215,8 & 193 \\
8 & Miscellaneous manufactured goods & $-45,7$ & $-35,6$ & $-47,7$ & $-63,6$ & $-62,4$ \\
9 & Products not elsewhere specified & $-21,8$ & 59,2 & 24,5 & 30 & $-22,4$ \\
\hline
\end{tabular}

Source: EUROSTAT.

What is the group of goods that makes the greatest deficit for the EU? That is goods group 3 - mineral fuels and lubricants. This is where Serbia can hardly seek for an opportunity to increase its export, since Serbia itself is a great importer of energy products. However, in further future the chance for export could be in electric energy, for the production of which there are large comparative advantages in Serbia, particularly in hydro-energy.

The EU has also a large foreign trade deficit in group 8 miscellaneous manufactured goods. The greatest minus is recorded in subgroups: clothing and shoes, furniture, miscellaneous craftsman products, optic and photo devices. This can be a great chance for export of the Republic of Serbia, and also a chance to recover numerous branches of manufacturing industry, that Serbia was once known for. These are first of all: textile industry, leather and shoes industry and furniture industry. Most of these industries are labor-intensive, which would have a great impact on reduction of unemployment in Serbia.

Another great minus that EU records is in goods group 2 - crude materials, except fuels. This cannot be an export opportunity for Serbia, because this group contains subgroups such as: metal ore, natural rubber, raw leather, textile fibers and other raw materials which are mostly imported in Serbia. Besides, basing export on group 2 is avoided even by countries that have comparative advantages in the raw material base.

What is the main asset of Serbia presently but also in the nearer future is goods group $0-$ food and live animals. The largest positive account in the foreign trade of Serbia is made in this group of goods, which is not flattering, since these are less sophisticated products, or in other words, products of a lower technological level. However, the comparative advantage that Serbia has in the production and export of this type of products is what "pulls out" Serbia from payment-balance insecurity that has been lasting for many years. A certain opportunity for 
export into the EU is fruits and vegetables, sugar and animal feed. We have already said that agriculture, as one of the carrying megasectors, can contribute to economic development not only with its fast development, but also with its influence on the increase of the total level of productivity of a country, which does not oppose new employment. A positive impact would also be felt by the development of rural areas, which have been experiencing real demographic catastrophe and even disappearance in the past few years. Fast development of agriculture would also affect the revival of numerous manufacturing capacities, which are directly dependent on it, but which have hit the rock bottom due to irresponsibility and neglecting of development policy. Finally, the increase in the level of the final processing of agricultural products can only be positive in the sense of export revenue of these products.

Group 4 - animal and vegetable fats are also one of the rare export assets of Serbia which also here records sufficit, and export possibilities to the EU are open.

What is left is to comment on certain items in other commodity groups in which Serbia could take active participation in their export to the EU. These are first and foremost non-ferrous metals, rubber production and inorganic chemical products. In the far future, this could also be the production of somewhat more sophisticated products of group 7 - machinery and transport equipment, which is not possible without new FDI and state investments in scientific-research projects.

\subsection{Services as an export opportunity of the Republic of Serbia}

Although the classical division of goods into tradable and nontradable indicates that services are non-tradable goods, i.e. that the deficit of the balance on goods cannot be covered with it, we cannot agree with this statement which is confuted by the reality of modern conditions. Not only are services tradables, but it is possible to make a nice profit with them in the international trade.

It has been already mentioned that special attention in the current balance of the Republic of Serbia is deserved by the balance on services, which has traditionally recorded surplus for a number of years (even decades). This "surplus" is by far not enough to cover the large deficit of the balance of goods, but it can be a clear indicator to policymakers that helps identify and stimulate future export sectors.

By taking a look at the balance on services of the Republic of Serbia, one can immediately perceive a positive fact that its account has been rapidly enlarged over the past years. This should be a good orienting point to policymakers in which direction they should move and which sectors should be especially stimulated. Over the past five years, the surplice in the trade in services of the Republic of Serbia has been increased for almost 8 times and most of the items of the balance on services have recorded 
surplus. The largest increase in surplus is recorded in items: professional and management consulting services, services in research and development, telecommunication services, telecommunications, computer, and information services, manufacturing services on physical inputs owned by others and other business services. It is an interesting fact that the Republic of Serbia has recorded deficit in tourism in the past few years, although there are comparative advantages for the development of this sector. Deficit is also recorded in transport, which has recorded one of the largest sectoral productivity in the Republic of Serbia recently, as well as a positive reallocation effect (increased employment in the sector would additionally increase productivity). This should be a clear warning to the state carefully to choose strategic goals and directions of economic development and consequently to choose adequate economic policy.

Table 11. Balance of services of Republic of Serbia (mil. EUR)

\begin{tabular}{lrrrrr}
\hline & 2012 & 2013 & 2014 & 2015 & 2016 \\
\hline Services total & 112 & 313 & 466 & 725 & 895 \\
Manufacturing services on physical inputs & 116 & 143 & 162 & 164 & 203 \\
$\quad$ owned by others & & & & & \\
Maintenance and repair services n.i.e. & -2 & 8 & 17 & 25 & 10 \\
Transport & -78 & -29 & -10 & -45 & -70 \\
Travel & -86 & -49 & -26 & -48 & -45 \\
Construction & 78 & 114 & 169 & 152 & 107 \\
Insurance and pension services & -24 & -18 & -25 & -14 & -18 \\
Financial services & -21 & -29 & -37 & -38 & -31 \\
Telecommunications, computer, and & 108 & 159 & 200 & 318 & 408 \\
$\quad$ information services & & & & & \\
Other business services & 124 & 145 & 157 & 208 & 273 \\
Research and development services & 5 & 0 & 8 & 35 & 46 \\
Professional and management consulting & 28 & 55 & 72 & 92 & 118 \\
$\quad$ services & & & & & \\
Technical, trade-related, and other business & 312 & 91 & 78 & 81 & 109 \\
$\quad$ services & & & & & \\
Personal, cultural, and recreational services & 48 & 44 & 37 & 72 & 97 \\
Government goods and services n.i.e. & -42 & -42 & 39 & -34 & -35 \\
\hline$\quad$ Source: own calculations based & & & & & \\
\hline
\end{tabular}

Source: own calculations based on the data of the National Bank of Serbia.

In this paper we have mentioned several times that the $\mathrm{EU}$ is the largest foreign trade partner of the Republic of Serbia, and this is also the case in the field of services. Below, we will take a look at an excerpt from the balance on services of the EU, more precisely on a peart which shows negative balance in some service items. Our intention is to draw conclusion on potential increase in export of certain services of the Republic of Serbia into the EU. 
Table 12. Negative positions of the EU balance of services (billion EUR)

\begin{tabular}{lrrrrr}
\hline & 2012 & 2013 & 2014 & 2015 & 2016 \\
\hline Air transport & 5,5 & $-2,1$ & $-1,6$ & $-0,8$ & - \\
Other transport & $-0,3$ & $-0,9$ & $-0,4$ & $-1,1$ & - \\
Railway transport & $-0,1$ & $-0,03$ & $-0,05$ & $-0,1$ & - \\
Goods transport by roads & $-1,2$ & $-0,2$ & $-1,3$ & $-2,1$ & - \\
Postal and courier activities & $-0,3$ & $-0,7$ & $-0,3$ & $-0,6$ & - \\
Intellectual property use & $-7,8$ & $-6,3$ & $-19,5$ & $-37,1$ & $-47,1$ \\
Personal cultural and recreational services & $-1,4$ & $-1,9$ & $-3,5$ & $-2,8$ & 0,02 \\
R\&D services & $-1,4$ & 1,2 & $-1,2$ & -14 & $-32,5$ \\
\hline
\end{tabular}

Source: own calculations based on the EUROSTAT data.

Already at the first glance it is clear that the Republic of Serbia can seek for its services export opportunity in exporting services in research and development (which is indeed the intention of the Government of the Republic of Serbia), personal, cultural and recreational services (for which there are undoubtedly comparative advantages), as well as services of certain types of transport.

Beside the EU, the largest exporter of manufacturing services on physical inputs owned by others is China. Asian countries such as Japan and South Korea are large importers of these services, so perhaps attention should be drawn to this Asian region (World Trade Organization, 2016).

Concerning construction, Serbia is traditionally regarded as one of the most respectable countries in Europe that has been exporting highquality services in this sector around the world for many decades. Beside the traditional Russian market, the future strategy should also count on fastgrowing market of the Middle East and countries such as Kuwait, UAE, Qatar and Saudi Arabia, whose need for construction services permanently increases year after year (World Trade Organization, 2016).

What has increased in the past few years is export of telecommunications, computer, and information services of the Republic of Serbia. In this regard one should pay attention to countries such as Russia, Singapore and Japan, which have great needs for this type of services and at the same time record large deficits in foreign trade with this type of services (World Trade Organization, 2016). Having in mind that this is highly sophisticated set of services which have large value added and demand high qualified workforce, strategy makers and policymakers in the Republic of Serbia should recognize the importance of this sector and stimulate even more its development and speed up the connection with scientific and research institutions.

A set of personal, cultural and recreational services is also very interesting, and their additional development in the Republic of Serbia would not ask for large investments, because there are already comparative advantages in this sector of services. Large deficits in this item are recorded by countries around the world, which means that the export opportunities 
are great. The largest deficits are recorded by countries such as Canada, India, Australia, Brazil, Switzerland, Russia, Norway, Qatar, so the Republic of Serbia can seek for the opportunities to increase the export on literally all continents (World Trade Organization, 2016).

The largest participants in foreign trade in services are the most developed countries of the world, but also some developing countries (so called emerging markets) (Ingham, 2004). Countries such as Japan, Switzerland, Brazil, South Korea and Russia are possible markets Serbia should pay attention when considering stimulation of this sector on services (World Trade Organization, 2016).

\section{CONCLUSION}

The field of international trade and international trade policy is one of the most attractive fields not only in academic circles. Sufficit in the balance on goods has always been regarded as a sign of prosperity of a country, regardless of the methods of its realization. Deficit, on the other hands, has been always a sign of inadequate and unsuccessful economic policy (Todaro, Smith, 2003).

Having in mind the payment balance situation in the Republic of Serbia, it can be concluded that it is unfavorable because of relatively large deficit of the current balance, which is caused by the huge deficit of the balance on goods. However, the problem is not of the balance of payment nature, but rather of structural and even systemic nature.

The poor economic structure and disoriented structural transformation that have been lasting for many years, have caused poor structure of export supply of the Republic of Serbia, and in this way revealed comparative advantage has been identified in sectors such as food and live animals, beverages and tobacco, animal and vegetable fats and miscellaneous finished products. In other groups of goods there are no revealed comparative advantages (the RCA index is negative). Looking at the vertical economic structure of the Republic of Serbia, it is clear that manufacturing industry participates with the largest share in creating gross national product of the Republic of Serbia, and it also employs the largest number of workers, so it can be justly considered the most important (driving) sector in the economy. The largest comparative advantage of the manufacturing activities are shown in the production of tobacco products, then furniture, beverages and food production. Other sectors that are also worthy of attention are: production of clothing items, metal products other than machines and devices, rubber and plastic products. Having in mind that these are mostly activities that produce items of low value added, we can conclude a poor export outlook.

The future strategy of restructuring of economy and foreign trade of the Republic of Serbia should identify carrying sectors of the economy of Serbia, the backbone of economic development and export. The structure of 
the economy of Serbia should be "set" in the way that it provides long-term stable economic growth and to reduce the disbalance of the balance of payment, to increase the competitiveness of the economy, to reduce unemployment and finally to increase the standard of living. Observing sectors in the international trade is of crucial importance for the future strategy of economic restructuring of Serbia, and thus for the increase in effects of export. Having in mind that manufacturing industry is the most important sector of the Republic of Serbia, it is a logical starting point of production for the international market. The Republic of Serbia should emphasize not only the increase of export of manufacturing products to the EU countries, but also to other world markets, such as USA, China, India and Japan.

It is logical that the Republic of Serbia should use its comparative advantages primarily in export to the EU, because it is our biggest foreign trade partner. Special attention should be given to the following groups of products: group 3 (energy products); group 8 (miscellaneous finished products), subgroups clothing items and shoes, furniture, different crafts products, optic and photo devices; group 0 (food and live animals), which is the strongest export group for Serbia at the moment but also in the nearer future; group 4 (animal and vegetable fats).

In the current balance of the Republic of Serbia, special attention is to be given to the balance on services, which traditionally records surpluses for a long period of decades. A positive fact that its account has been rapidly increased over the past few years can be immediately seen, which should be a good orientation point to policymakers. The largest growth of sufficit is recorded in: professional and management consulting services, telecommunications, computer, and information services, services in research and development, manufacturing services on physical inputs owned by others and other business services. Some negative trends should also be mentioned, for instance that the Republic of Serbia has been recording deficit in tourism for the past few years, although there are large comparative advantages for the development of this sector; deficit has been also recorded in transport, which, on the other hand, has recorded one of the largest sectoral productivities in the Republic of Serbia in recent years, as well as the positive reallocation effect (increased employment in the sector in order to increase productivity). This should be a clear warning to the state to carefully choose their goals and directions of economic development and consequently design adequate economic policy. This is the only way to avoid negative economic and systemic influences on the export effects. 


\section{REFERENCES}

Aranđelović Z., Marjanović V., Petrović-Ranđelović M. (2013). Structural Changes in the Light of new Industrial Strategy. Ekonomika preduzeća, septembaroktobar 2013 (373-385). Beograd: Društvo ekonomista Srbije.

Arsić M., Ranđelović, S., Brčerević, D. (2015). Ekonomska poltika i srednjoročne ekonomske perspektive Srbije[Economic politics and mid-term economic perspectives of Serbia]. Ekonomska politika Srbije u 2015. godini. Beograd: NDE.

Directorate General for Trade. (2017). European Union, Trade with Serbia. Brussels: European Commission.

IMF. (2017). World Economic Outlook 2017 (Gaining Momentum?). World Economic and Financial Surveys. Washington: IMF.

Ingham, B. (2004). International Economics (A European Focus). Harlow: Pearson Education.

Krugman, P., Obstfeld, M. (2000). International Economics-Theory and Policy. New York: Addison Wesley.

Marjanović V., Petrović-Ranđelović M. (2012). Strategija restrukturiranja privrede Srbije.[Strategy of Restructuring Serbian Economy] Nauka i svetska ekonomska kriza, knjiga druga (97-87). Niš: Ekonomski fakultet.

Narodna banka Srbije. (2017). Statistički bilten 2017 [Statistical Bulletin]. Beograd: Narodna banka Srbije.

Nikolić, G. (2008). Karakteristike robne razmene Srbije sa zemljama EU: rezultati i očekivanja. [Characteristics of Goods Exchange of Serbia with the Countries of the EU: results and expectations] Beograd: PKS.

Ohlin, B. (1935). Interregional and International Trade. Cambridge: Harvard University Press.

Republički zavod za statistiku. (2016). Statistički godišnjak 2016. [Statistical Annual Report 2016] Beograd: Republički zavod za statistiku.

Serbian Development Agency. (2016). Why Invest in Serbia? Belgrade: Serbian Development Agency.

Todaro, M., Smith, S. (2003). Economic Development, Eight Edition, Harlow: Addison Wesley.

WTO. (2016). World Trade Statistical Review 2016. Geneva: WTO.

\section{Links}

http://ec.europa.eu/eurostat http://www.stat.gov.rs/WebSite/Default.aspx

https://www.nbs.rs/internet/cirilica/index.html 


\title{
ИСКОРИШЋЕЊЕ КОМПАРАТИВНИХ ПРЕДНОСТИ РЕПУБЛИКЕ СРБИЈЕ У ФУНКЦИЈИ ПОВЕһАЊА ЕФЕКАТА ИЗВОЗА
}

\author{
Владислав Марјановић, Маја Марјановић \\ Универзитет у Нишу, Економски факултет, Ниш, Србија
}

Резиме

Имајући у виду спољнотрговинску позицију Републике Србије, може се констатовати да је она већ дужи низ година неповољна и комликована. Главни узрочници јесу наслеђени економски проблеми, али и новонастали екстерни и интерни утицаји. Тачније речено, велики структурни проблеми, као и проблеми изазвани економском политиком, главни су узрочници дефицита текућег биланса Републике Србије. Оваква неповољна комбинација структурних и системских фактора захтева посебну пажњу у конципирању будуће стратегије (и политике) спољне трговине Републике Србије. Она би требало да уважи све компаративне предности у циљу повећања извоза.

У раду је коришћен метод квантитативне анализе, којим је мерен индекс откривених компаративних предности RCA, сектора према међународној трговинској класификацији, што је најједноставнији пут за сазнавање који би сектори могли бити окосница будућег извозног залета Републике Србије.

У раду су потврђене хипотезе да је главни узрочник платнобилансних проблема Републике Србије хроничан дефицит робног биланса, да дефицит робног биланса узрокују структурни и привредно-системски проблеми, да Република Србија нема адекватну извозну понуду и да је једини начин да се дугорочно реши проблем дефицита, реструктурирање привреде и повећање извоза.

Хронични дефицит текућег биланса Републике Србије узрокују два фактора: неадекватна и релативно мала извозна понуда и погрешно структурирана и релативно велика увозна тражња. Због тога би безусловно требало повећати извозну понуду и управљати структуром тражње, а све у циљу остварења одрживог спољнотрговинског дефицита.

Јасно је да би будућа стратегија спољне трговине Републике Србије морала да зацрта као свој основни циљ повећање извоза. Основна детерминанта повећања извоза, пре свих, јесте реструктурирање привреде у правцу формирања и подстицања извозно-пропулзивних сектора. Овај процес неће бити могућ без додатне акумулације нити институционалне подршке.

Конкурентност је такође важна детерминанта повећања извоза, а с тим у вези и појачана промотивна активност државе у међународним оквирима. У профилисању будуће извозно оријентисане структуре Републике Србије, посебна пажња мора бити посвећена извозу услуга, који последњих година и деценија бележи динамичан раст у светским размерама. Уосталом, дугогодишњи позитиван салдо биланса услуга Републике Србије довољан је сигнал да на овај сектор морамо озбиљно рачунати у будућој структурној трансформацији, како по питању стварања друштвеног производа тако и по питању фузионисања вишка радне снаге из осталих сектора (пољопривреде и индустрије). Највећи број услужних грана у Републици Србији показује откривене компаративне предности, па би то требало искористити у циљу повећања извоза. 